Review article

\title{
Angiogenesis in Glioblastoma: Molecular and Cellular Mechanisms and Clinical Applications
}

\author{
Desanka Tasić2,4, Irena Dimov ${ }^{5}$, Miloš Kostov 6 , Nataša Vidović3, Dragan Dimov²,4 \\ ${ }^{1}$ University of Niš, Faculty of Medicine, Niš, Serbia \\ ${ }^{2}$ University of Niš, Faculty of Medicine, Retired professor, Niš, Serbia \\ ${ }^{3}$ Center for Pathology and Pathological Anatomy, Niš, Serbia \\ ${ }^{4}$ Center for Pathology and Pathological Anatomy, Retired pathologist, Niš, Serbia \\ ${ }^{5}$ University of Niš, Faculty of Medicine, Department of Immunology, Niš, Serbia \\ ${ }^{6}$ Institute of Forensic Medicine, Niš, Serbia
}

SUMMARY

Glioblastoma (GBM) is the most common malignant primary brain tumor in adults and carries poor prognosis. Despite advances in therapy, no significant increase in survival has been achieved for GBM patients. These tumors inevitably recur in the majority of patients, and the therapeutic options for recurrent tumors are limited. GBMs are aggressive, fast-growing, and highly infiltrative tumors, with exuberant angiogenesis (microvascular proliferation) and necrosis. However, the newly formed tumor vessels are structurally and functionally abnormal, creating areas of hypoxia and ultimately necrosis, contributing to tumor progression and aggressiveness. Since GBMs are hypervascular in nature, targeting tumor angiogenesis emerged as a promising therapeutic strategy.

In this review, we summarized the molecular and cellular mechanisms governing GBM angiogenesis, the other modes of tumor vascularization, and the key mediators of these processes. We also discussed the importance of tumor hypoxia in promoting angiogenic and vasculogenic processes, the contributions of GBM stem cells to tumor vasculature, the anti-angiogenic therapy for GBM, and the resistance to such therapy. A better understanding of the molecular and cellular basis of GBM neovascularization, the mechanisms of resistance to therapy, and the contributions of GBM stem cells to tumor vasculature will lead to the development of more effective treatment strategies.

Key words: glioblastoma (GBM), angiogenesis, vasculogenesis, hypoxia, GBM stem cells, anti-angiogenic therapy, resistance

Corresponding author:

Desanka Tasić

email: desatasicdim@gmail.com 


\section{INTRODUCTION}

Glioblastoma (GBM) is the most common and the most aggressive form of malignant glioma in adults, with poor prognosis $(1,2)$. The World Health Organization (WHO) (1) classifies diffuse astrocytic gliomas into WHO grade II-IV on the basis of combined histopathological criteria and molecular parameters. Grade III (anaplastic astrocytoma) and IV (GBM) are considered malignant gliomas, and the presence of microvascular proliferation (MVP) and/or necrosis are the distinguishing features of GBM. This classification system has the implications for prognosis and management (1). Despite advances in therapy, no significant increase in survival has been achieved for GBM patients (3). The median survival after standard therapy, including surgery, radiation, and temozolomide is 15 months (4). These tumors inevitably recur in most patients, and the therapeutic options for recurrent tumors are limited (5).

GBMs are characterized by rapid growth, widespread invasiveness, exuberant angiogenesis, intravascular thrombosis, and necrosis $(2,6-8)$. In a large histopathological analysis, intravascular thrombosis was found in $92 \%$ of all primary GBM resection specimens (6). Tumor necrosis manifests as a large ischemic necrosis or as microscopic foci surrounded by pseudopalisading cells (7-9). These tumor cells are hypoxic and secrete pro-angiogenic factors to elicit the angiogenic response (7-10). Tumor angiogenesis is fundamental to the propagation of GBMs (11-16). However, the newly formed tumor vessels are structurally and functionally abnormal, creating the areas of hypoxia and ultimately necrosis, thereby contributing to tumor progression and aggressiveness $(8,9,11,13,14,17,18)$. Hypoxia can promote tumor cell invasion and genetic instability, as well as the resistance to radiation and chemotherapy $(7,11,17)$.

The majority of GBMs arise de novo (primary GBMs) and develop rapidly in older patients, while the tumors that progress from lower grade (grade II or III) - astrocytic gliomas, termed secondary GBMs, develop in younger patients (2). Primary and secondary GBMs present distinct genetic alterations, including the frequently occurring IDH1 (isocitrate dehydrogenase 1) gene mutation in secondary GBMs that confers a better prognosis and is already present in the precursor lesions $(19,20)$. According to the 2016 WHO classification that incorporates the molecular features like IDH status, GBMs are divided into IDHwild type GBM ( $\sim 90 \%$ of cases corresponds to pri- mary or de novo GBM) and IDH-mutant GBM ( 10\% of cases corresponds to secondary GBM) (1). With the transition to GBM, dramatic histopathological changes occur and reflect a profound alteration in the tumor vascular biology (18). MVP (an exuberant form of angiogenesis) is the hallmark of both GBM subtypes $(2,8,11,15)$. Since GBMs are hypervascular in nature, targeting tumor angiogenesis emerged as a promising therapeutic strategy. Several anti-angiogenic agents have been evaluated in clinical trials (13, 17, 21-24).

In this review, we summarized the molecular and cellular mechanisms governing GBM angiogenesis and the other modes of tumor vascularization, as well as the key mediators of these processes. We also discussed the importance of tumor hypoxia in promoting angiogenic and vasculogenic processes, the contributions of GBM stem cells to tumor vasculature, the anti-angiogenic therapy for GBM, and the mechanisms of resistance to therapy.

\section{REGULATION IN GBM ANGIOGENESIS: MOLECULAR MECHANISMS}

The growth of GBMs depends critically on the development of new blood vessels which are predominantly derived from the existing vasculature by a process known as angiogenesis $(12-16)$. This process is primarily driven by vascular endothelial growth factor (VEGF), but there are numerous other pro-angiogenic factors involved in GBM angiogenesis, including angiopoietins, platelet-derived growth factor (PDGF), basic fibroblast growth factor (bFGF), interleukin-8 (IL-8), and hepatocyte growth factor/ scatter factor (HGF/SF) $(12,13,15,25$ - 27). Tumor hypoxia and hypoxia-inducible factor-1 (HIF-1) are considered to be crucial in GBM angiogenesis (8 - 11, $18,25,27)$.

\section{The VEGF family members and VEGF receptors}

The VEGF family includes VEGF-A, -B, -C, -D, -E, -F and placental growth factor (PIGF) $(12,18,25$, $27,28)$. Out of these, the family members VEGF-A, VEGF-B, and PIGF are involved in angiogenesis, whereas VEGF-C and VEGF-D promote lymphangiogenesis (12). VEGF-A, known as VEGF and discovered as the vascular permeability factor, is a highly specific mitogen for endothelial cells (ECs) $(11,12,28)$. It also promotes EC migration and 
invasiveness, which are required for angiogenesis $(12,18)$. VEGF (VEGF-A), the key regulator of physiological and pathological angiogenesis, is highly expressed in GBMs (11-13, 18, 25). Human VEGF has four major isoforms (VEGF121, VEGF165, VEGF189, and VEGF206), which are generated by alternative splicing and have a different capacity of heparin-binding and functions in angiogenesis (12, $27,28)$. The two large VEGF isoforms represent a reserve of VEGF, whereas the smaller (soluble) isoforms have either a high (VEGF165) or low (VEGF121) mitogenic potential (3). In most human tissues, VEGF165 is found to be the most abundant isoform $(12,28)$. With VEGF165 being the predominant isoform expressed in a variety of human tumors (25), VEGF121 and VEGF189 were also detected in GBMs (12).

The VEGF isoforms exert their function by binding to VEGF tyrosine kinase receptors (TKRs). VEGFR-1 (Flt-1) and VEGFR-2 (KDR/Flk-1) are the major receptors on vascular ECs, whereas VEGFR-3 (Flt-4) is expressed mainly on lymphatic ECs and is thought to be involved in lymphangiogenesis $(12,18$, 28). VEGFR-2 is the main mediator of several effects of VEGF on ECs, including survival, proliferation, migration, and permeability $(12,13,25,28,29)$. VEGFR-1 binds VEGF with a higher affinity than VEGFR-2, but its signal-transducing properties are weak (29). Thus, VEGFR-1 may act as a "decoy" receptor that regulates the availability of VEGF for VEGFR-2 $(12,28)$. However, upon the binding of PIGF, VEGFR-1 may positively regulate angiogenesis (12). The observation that many types of tumor cells, including glioma and GBM cells, express VEGFRs (especially VEGFR-1) and also produce VEGF (18, $29,30)$ indicates that VEGF may act as an autocrine growth factor for tumor cells (29). Neuropilins (NRP1 and NRP-2) are VEGF co-receptors, enhancing the functions of VEGFR-2, but also signaling independently (18). In addition to soluble VEGFRs (like sVEGFR-1), soluble NRP-1 can also sequestrate VEGF, reducing its pro-angiogenic activity (13).

The intratumoral levels of VEGF and its receptors correlate with the grade of gliomas (11 - 13, 25). In GBMs, VEGF is highly expressed in hypoxic pseudopalisading tumor cells around necrotic foci (8 - 11, 18). Hypoxia induces the transcriptional activation of VEGF through HIF-1 and both VEGFR-1 and VEGFR-2 are induced by HIF-1 in ECs $(11,18)$. Additionally, cytokines and growth factors (such as epidermal growth factor, PDGF-B, bFGF) upregulate
VEGF, and the genetic alterations commonly seen in GBMs, including EGFR amplification and PTEN (phosphatase and tensin homolog) mutation or loss, enhance VEGF expression $(2,12,15,25)$. Hence, the upregulation of VEGF expression in highly vascularized GBMs is probably the result of the accumulation of genetic alterations and hypoxia (11). Tumor cell-released VEGF stimulates EC growth and proliferation through paracrine signaling. VEGF can also be released from myeloid or other stromal cells and the extracellular matrix (ECM) $(13,29,31-33)$. ECs produce very low levels of VEGF, indicating that autocrine VEGF signaling maintains vascular homeostasis (34). VEGF has also been implicated in the recruitment of VEGFR-2-expressing endothelial progenitor cells (EPCs) which contribute to GBM neovascularization $(33,35)$.

\section{Angiopoietins and the Tie-2 receptor}

The Tie-2 TKR and its two major ligands, angiopoietin-1 (Ang-1) and Ang-2, are implicated in GBM angiogenesis. The Tie-2 receptor expressed on ECs is a potent angiogenic regulator involved in vessel remodeling and maturation and EC survival $(18,26)$. Ang-1 binding causes Tie-2 receptor phosphorylation and protects ECs from apoptosis, and this effect is antagonized by Ang- $2(18,36)$. Ang1 stabilizes blood vessels, by promoting the interactions between ECs and pericytes, and prevents the leakiness of vessels, whereas Ang-2 destabilizes the existing vasculature, promotes vessel sprouting, and new vessel growth in the presence of VEGF $(11,18$, $26,36)$. In the absence of VEGF, Ang-2-induced Tie-2 receptor blockade causes EC apoptosis and vessel regression $(8,25,26,36)$. Not only ECs but also pericytes secrete Ang-1 (29). In normal blood vessels, pericytes suppress EC proliferation and release cellsurvival signals (such as VEGF and Ang-1) $(37,38)$. Quiescent ECs have long half-lives. Through the interaction with VE-cadherin, VEGF and Ang-1 are critical survival factors (13).

The Ang-2 expression is absent in the normal brain vasculature but is induced in the ECs of the coopted blood vessels by glioma cells $(25,36)$. Ang- 1 and Ang-2 acting in concert with VEGF are involved in the stability and maintenance of the tumor vasculature. The levels of Ang-1, Ang-2, and Tie-2 are greatly elevated in GBM samples (18). Ang-1 is expressed mainly by the tumor cells, whereas Ang-2 and Tie-2 expressions are localized to the tumor 
vasculature and the invasive edge of the tumor (18, 26). The increased expression of Ang-2 on GBM vasculature appears early during angiogenesis $(8,25$, 36). It can enhance tumor angiogenesis by recruiting pro-angiogenic Tie-2-expressing monocytes (TEMs) (39). Ang-2 has also been implicated in glioma cell invasion by matrix metalloproteinase-2 (MMP-2) (26, 27) activation. While little is known of the Ang- 1 regulation, Ang-2 and Tie-2 are induced by hypoxia via HIF-1 $(11,18)$. Alternatively, Ang-2 expression may be induced by VEGF, rendering ECs more accessible to its effects $(11,26)$.

\section{Other angiogenic factors}

In addition to VEGF and angiopoietins, numerous other factors that stimulate angiogenesis in GBM, including PDGF, bFGF, HGF/SF, IL-8, stromal cell-derived factor- $1 \alpha$ (SDF-1 $\alpha$ ), Notch signaling, and integrins $(13,15,25,27,38)$, exist.

PDGF isoforms (PDGF-A,-B,-C and-D) and their receptors (PDGFR- $\alpha$ and $-\beta$ ) have been implicated in both gliomagenesis and angiogenesis. PDGF-A, PDGF-B, and PDGFR- $\alpha$ are overexpressed in gliomas, particularly in high-grade tumors $(2,27)$. The upregulation of PDGFR- $\alpha$ is localized in tumor cells, whereas the strong expression of PDGFR- $\beta$ occurs in proliferating ECs in GBMs (2). The tumoral co-expression of PDGF and PDGFR suggests that both autocrine and paracrine loops play roles in GBM. For example, the stimulation of PDGFR- $\beta$ expressing ECs by the tumor-derived PDGF-B has been shown to enhance angiogenesis and glioma growth in mice; these effects are partly mediated by VEGF (40). The PDGF-B isoform can upregulate VEGF and exert effects on endothelial and perivascular cells $(13,15,25)$.

Basic FGF (FGF-2), the first pro-angiogenic factor discovered, is a potent mitogen for ECs and has been implicated in GBM angiogenesis (13). Both acidic FGF (FGF-1) and bFGF are upregulated in GBMs and are responsible for the resistance of ECs to apoptosis $(15,25)$. Similarly to VEGF, these FGFs induce EC proliferation and migration (15). Basic FGF has the ability to upregulate VEGF expression $(15,25)$. This FGF can be released from tumor and other cells (such as ECs, peri-ECs, and TEMs) and the $\operatorname{ECM}(27,31,32,39)$.

HGF/SF and its receptor c-Met are overexpressed in both tumor cells and ECs in GBM samples $(9,15)$. HGF/SF has been shown to exert strong pro-angiogenic effects in vitro and causes the upregulation and secretion of VEGF by glioma cells (9). The overexpression of HGF/SF in xenografted gliomas leads to increased angiogenesis and tumor growth in mice $(9,27)$. Importantly, the receptor cMet is upregulated by hypoxia $(9,16,25)$.

IL-8 (CXCL8) is a chemokine with a proangiogenic activity that is highly upregulated in GBMs (41). The highest expression was found within pseudopalisades of GBM, suggesting that hypoxia stimulates its expression $(7-9,41)$. The IL-8 promoter contains a binding site for transcription factors NF$\kappa B$ and activator protein-1 (AP-1), among others. AP1 has been shown to mediate IL-8 upregulation by hypoxia in gliomas $(9,13)$. The IL-8 receptors that contribute to IL-8-mediated tumorigenic and angiogenic responses include CXCR1 and CXCR2, both of which are G-protein- coupled, and the Duffy antigen receptor for cytokines, which has no defined intracellular signaling capabilities (41).

The chemokine SDF-1 $\alpha$ (CXCL12) and its receptor, CXCR4, are both elevated in GBMs and play a role in tumor neovascularization and invasiveness $(10,35,42)$. A marked colocalization of CXCR4 and SDF- $1 \alpha$ was found in GBM cells, mainly in the areas of pseudopalisading necrosis, as well as in the vascular endothelium (13). SDF- $1 \alpha$ is also involved in the recruitment of the bone marrowderived cells (BMDCs) that contribute to GBM neovascularization $(33,35)$.

The Notch signaling pathway is an important contributor to tumor angiogenesis $(13,29)$. Delta-like ligand 4 (DLL4) belongs to the Delta/Jagged family of transmembrane ligands that bind to the Notch receptors (43). The DLL4-Notch pathway is involved in many biological processes, including angiogenesis $(13,43)$. VEGF signaling through VEGFR-2 upregulates DLL4 expression in endothelial (migratory) tip cells, which, in turn, activates the Notch receptor on the neighboring endothelial (proliferating) stalk cells $(29,38)$. This results in the downregulation of VEGFR-2 and a reduction in the sprouting activity of VEGF. The DLL4-Notch signaling inhibits tip cell formation $(13,44)$ and promotes the orderly development of new blood vessels (29). Overall, the DLL4Notch signaling restricts branching but generates perfused vessels (38). Jagged1, another Notch ligand expressed by stalk cells, promotes tip-cell selection (44). Jagged1 is a pro-angiogenic regulator that antagonizes DLL4-Notch signaling (44). DLL4 is also upregulated in the tumor vasculature $(29,43)$, and 
the inhibition of DLL-4 increases tumor angiogenesis, but the majority of newly formed vessels are abnormal and hypoperfused, resulting in tumor hypoxia and growth inhibition (43). In GBMs, the DLL4-Notch pathway is activated $(3,45)$, and DLL4 and Notch4, but not Notch1, were found to be overexpressed in tumor vasculature (45). DLL4- and Jagged1-expressing GBMs are likely sensitive to antiVEGF therapy, while GBMs that are DLL4-positive and Jagged1-negative are resistant to anti-VEGF treatment (3).

In addition to Notch, the proteins associated with neuronal guidance, such as Semaphorins, Ephrins, Slits, and Netrins and their receptors, also have a role in the angiogenic process $(13,46)$. For example, NRP-1 is the co-receptor for both Semaphorin and VEGF and, thus, can modulate angiogenesis. Semaphorin binding to the Plexin D1 receptor limits the angiogenic potential of VEGF (46). Moreover, the local expression of VEGF can dictate the fate of a cell to the tip or the stalk by controlling the expression of the Plexin D1 receptor, which upon binding Semaphorin 3E negatively regulates the DLL4-Notch pathway (46).

Integrins are heterodimeric membrane receptors that mediate cell adhesion to ECM proteins and play a significant role in angiogenesis. The upregulation of the integrins $\alpha v \beta 3$ and $\alpha v \beta 5$ on the activated ECs promotes the EC spreading and migration through the ECM (47). Other integrins involved in angiogenesis include $\alpha 1 \beta 1, \alpha 2 \beta 1, \alpha 4 \beta 1$, $\alpha 5 \beta 1, \alpha 9 \beta 1$, and $\alpha 6 \beta 4$ (47).

The above-mentioned stimulators of angiogenesis are opposed by a number of endogenous angiogenesis inhibitors, including angiostatin, endostatin, thrombospondin-1 and -2, vasculostatin, tumstatin, vasohibin, and interferons $(25,29)$. When stimulatory factors outweigh inhibitors, the angiogenic switch favors blood vessel formation.

\section{Hypoxia and HIF-1 in GBM angiogenesis}

Hypoxia is considered a major driving force of GBM angiogenesis (11). In hypoxic conditions, tumor cells undergo metabolic alterations and adaptive mechanisms through the activation of HIF1 , a key heterodimeric transcription factor composed of HIF- $1 \alpha$ and HIF-1 $\beta$ subunits. While the HIF- $1 \beta$ subunit is constitutively expressed, the HIF- $1 \alpha$ subunit is hypoxia stabilized. Under normoxia, HIF-
$1 \alpha$ is hydroxylated by prolyl hydroxylase (PHD) enzymes, resulting in a rapid ubiquitination mediated by the von Hippel-Lindau protein ( $p$ VHL) and a subsequent proteasomal degradation $(11,18$, $25)$. Under hypoxia, PHD enzymes become inactive, and HIF- $1 \alpha$ accumulates and translocates to the nucleus where it dimerizes with HIF-1 $\beta$ and binds to the hypoxia-response elements (HREs) of the target (hypoxia-inducible) genes. The HIF-1 activates the transcription of $>100$ target genes that control cell survival, metabolism, motility, and angiogenesis (11, $18,25,48)$.

HIF- $1 \alpha$ is a potent activator of tumor angiogenesis, primarily by the upregulation of VEGF. In GBMs, HIF- $1 \alpha$ is highly expressed in pseudopalisading tumor cells adjacent to necrosis, colocalizing with the upregulated VEGF $(7-11,49)$. A positive correlation between HIF- $1 \alpha$ and VEGF levels and tumor vascularity has been reported (12, 49). HIF- $1 \alpha$ binds to the HRE in the VEGF promoter region to increase the VEGF expression $(11,18,25)$. It can also stabilize the mRNA of VEGF (11). Besides VEGF, HIF- $1 \alpha$ stimulates the expression of other angiogenic factors such as PlGF, PDGF-B, and Ang2 , as well as the molecules that are implicated in angiogenesis such as MMPs (like MMP-2), urokinase plasminogen activator receptor (uPAR), endothelin1 , inducible nitric oxide synthase (iNOS), transforming growth factor- $\beta$ (TGF- $\beta$ ), and adrenomedullin $(11,18,25,27)$. Additionally, the HIF-1 $\alpha$ induced genes, which include SDF- $1 \alpha$ and CXCR4, are known to be upregulated in GBMs $(10,13,33$, 35). The levels of CXCR4 correlate directly with those of HIF- $1 \alpha$ in the hypoxic areas of GBMs (10). The expression of HIF- $1 \alpha$ in glioma cells induced the expressions of VEGF and CXCR4. In turn, the VEGFmediated CXCR4 expression in ECs enhances tumor angiogenesis (10).

In addition to the hypoxia-induced upregulation of HIF- $1 \alpha$, there are oncogenes and tumorsuppressor genes which modulate the HIF-1 $\alpha$ expression or activity. For example, the expression of a mutant EGFR (EGFRvIII) or the loss of PTEN function of glioma cells leads to an increased HIF- $1 \alpha$ expression through the PI3K (phosphatidylinositol 3kinase)/AKT pathway $(11,12,18,25)$. The tumorsuppressor p53 may inhibit the HIF-1 activity in hypoxia by promoting the degradation of HIF- $1 \alpha$ and competing for the transcriptional co-activator p300 $(11,18,25)$. In addition, several growth factors 
(such as EGF, TGF- $\alpha$, PDGF-A, insulin-like growth factor-1 and -2) also modulate the expression of HIF$1 \alpha(11,27)$.

The second HIF- $\alpha$ subunit, HIF- $2 \alpha$, is also upregulated in GBMs $(11,25)$. HIF- $1 \alpha$ and HIF- $2 \alpha$ are highly homologous and share some of the target genes, including those encoding VEGF and glucose transporter GLUT-1 (48). Recent studies have shown that HIF- $2 \alpha$ is preferentially expressed in GBM stem cells (GSCs), regulating the stemness of GSCs and their role in promoting tumor vascularization and growth $(50,51)$.

\section{MECHANISMS OF NEOVASCULARIZATION IN GBM}

Neovascularization in GBM occurs predominantly through angiogenesis (sprouting of vessels) (12 - 16, 25, 27). The development of GBM vasculature may also occur through other mechanisms, including vasculogenesis which involves the recruitment of EPCs $(33,35)$ and vasculogenic mimicry, in which tumor cells (GSCs) form vascular channels (52). There is evidence indicating that tumor cells can obtain the necessary nutrients and oxygen by co-opting the preexisting blood vessels (vessel co-option) (36). Notably, these different mechanisms of vascularization can occur in the same tumor $(38,53)$. Tumors can also increase neovascularization by intussusception. This mechanism is thought to represent vessel formation through the split of the pre-existing vessels into daughter vessels (38). Intussusceptive vascular formation is faster than sprouting angiogenesis and has been seen in murine models of colon and lung cancer metastasis in the brain (13).

\section{Co-option of existing blood vessels}

The studies of experimental glioma models have provided evidence that tumor growth in the brain follows two vascular phases $(25,36)$. In the first phase, the existing brain blood vessels are co-opted by tumor cells, while in the second phase, there is a true neovascularization arising from the existing vessels. In the rat C6 glioma model, the co-option of the existing brain vasculature by tumor cells initially occurred when the tumors were several millimeters in diameter, followed by the vascular regression and, ultimately, by angiogenesis (36). According to this view, tumor cells accumulate first around the existing vasculature and lift off the astrocytic foot processes which lead to the mechanical disruption of the normal contact between ECs and the basement membrane (25). The affected ECs of the co-opted vessels express Ang-2, resulting in the destabilization of the vessel wall and a decreased pericyte coverage $(25,26,36)$. The perivascular proliferation of tumor cells, compression, and destabilization of blood vessels leads to vessel regression and reduced perfusion. This causes hypoxia and the death of neighboring tumor cells and the formation of a necrotic area $(25,36)$. Hypoxia and genetic alterations in tumor cells induce the secretion of growth factors that recruit new blood vessels through angiogenesis $(7-9,11-13,25)$.

Unlike GBMs, lower grade astrocytic gliomas are unable to promote angiogenesis but are capable of propagating by co-opting the dense normal brain vasculature $(14,53)$. The co-opted brain vessels can also support GBM growth, especially at the infiltrating tumor edge (2). Additionally, tumors can evade anti-angiogenic therapy by vessel co-option that supports a more invasive tumor cell phenotype and tumor growth $(53,54)$. Moreover, highly infiltrative brain tumors with a stem-cell-like phenotype have been shown to co-opt the host vasculature and present as an aggressive disease without the signs of angiogenesis in the rat GBM models (55).

\section{Angiogenesis}

GBMs are among the most vascularized tumors with highly elevated levels of numerous proangiogenic factors $(2,8-13,15,25,27)$. VEGF acting through VEGFR-2 is thought to be the major tumor angiogenesis factor and is induced by hypoxia via HIF-1 $\alpha$ (11, 18). GBMs have a 50-fold greater expression of VEGF than normal brain tissue (12). Additionally, the levels of VEGF in the cystic fluid of GBMs are 200- to 300-fold higher than in the serum of patients (8). Experimental evidence suggests that vascular regression (after the co-optive growth) precedes angiogenesis in the development of glioma $(25,36)$. As previously noted, in the presence of tumor-derived VEGF, Ang-2 expressed on the affected ECs destabilizes blood vessels, through the disruption of the interactions between ECs and pericytes, and promotes vascular sprouting, thus enhancing VEGF stimulation. In this setting, Ang-2 causes structural changes of blood vessels that are acquired for sprouting angiogenesis without endo- 
thelial apoptosis $(8,9,25,36)$.

Proteolytic degradation of the vascular basement membrane and surrounding ECM by proteases like MMPs enables EC proliferation and migration, and exposes the ECs to ECM proteins that regulate the angiogenic cascade $(15,25,32)$. Both MMP-2 and MMP-9 are highly expressed in GBMs, whose expression is strongly induced by hypoxia $(7$, 8, 16, 18, 32). MMPs (like MMP-9) also liberate proangiogenic factors such as VEGF and bFGF from the immobilized matrix stores $(32,33,38)$. VEGF enhances tumor angiogenesis by stimulating the endothelial production of uPA (12), which induces the conversion of plasminogen to plasmin, causing the degradation of ECM components and leading to ECM remodeling (15).

Integrins $(\alpha v \beta 3, \alpha v \beta 5$, and $\alpha 5 \beta 1)$ are upregulated on ECs during angiogenesis to enhance the EC spreading and migration in response to growth factor signaling $(13,47)$. Integrins also interact with growth factors (such as VEGF and bFGF) and their receptors (VEGFR-2 and FGFR) stimulating vessel growth (27, $38,47)$. In addition, PDGF-B released by the activated ECs recruits pericytes to the site of newly sprouting vessels, where they aid in the formation of a new basement membrane $(37,40,56)$. It has been shown that the recruitment of pericytes to the developing EC tubes and EC-pericyte interactions facilitate vascular maturation and stabilization events, including basement membrane matrix assembly and the restriction of vascular tube diameter (57). Experimental data confirms the functional importance of pericytes in supporting the tumor vascular endothelium $(37,40$, 56, 58). Unlike physiological angiogenesis, tumor angiogenesis has lost the appropriate control mechanisms, enabling the constant growth of new tumor vessels (14). The end result of this process driven primarily by VEGF is the production of immature, dysfunctional and highly permeable vessels with an impaired blood-brain barrier (BBB) and a brain vasogenic edema (13).

\section{Vasculogenesis}

EPCs and pericyte progenitor cells (PPCs) may contribute to neovascularization in GBM. These vascular progenitors are mobilized from the bone marrow upon specific angiogenic stimuli. EPCs are incorporated into the vasculature and differentiate into ECs, while PPCs envelop blood vessels and mature into pericytes $(14,33,35,56)$. The circulating
EPCs (defined as CD34+/VEGFR-2+) have been shown to differentiate into ECs in vitro and incorporate into the blood vessels of ischemic tissues (59). During vasculogenesis, EPCs are mobilized from the bone marrow by chemokines, growth factors and other soluble factors, including SDF- $1 \alpha$, VEGF, PIGF, bFGF, and granulocyte-monocyte colony-stimulating factor (GM-CSF) $(13,60)$. Growth factors such as VEGF and PIGF induce MMP-9 expression in the bone marrow, which, in turn, cleaves and activates Kit ligand (stem cell factor, SCF), thereby permitting the mobilization of vascular progenitors into the peripheral circulation $(14,15)$. In patients with glioma, including GBM, circulating EPCs were found to be increasingly mobilized from the bone marrow and their mobilization correlated with the serum levels of VEGF and GMCSF and tumor vessel density $(61,62)$.

Studies investigating mouse GBM models have reported that the overexpression of VEGF and SDF- $1 \alpha$ (induced by hypoxia via HIF-1 $\alpha$ ) recruits EPCs to tumors, suggesting that SDF- $1 \alpha$ may be necessary for their retaining and incorporation into tumor vessels $(14,33,35)$.

The link between hypoxia and EPC recruitment is further supported by demonstrating that using vascular disrupting agents, which ablate tumor vessels and cause acute hypoxia and necrosis, can trigger EPCs to the tumor margins, thus facilitating revascularization (63). The reported levels of the incorporation of EPCs into various mouse GBM models varies considerably, ranging from 0.2 to $26 \%$ of vessels $(14,33,35)$. The frequency of EPC incorporation correlated with the hypoxic status of GBM models (35). For example, in the GBMs lacking HIF$1 \alpha$, the hypoxic response was impaired with the decreased levels of VEGF and SDF- $1 \alpha$, and subsequently reduced the incorporation of EPCs into the tumor vessels (33). These data reveal that gliomas recruit EPCs at a modest rate when they undergo rapid growth and become highly hypoxic (such as GBMs) (14).

Apart from a local origin, pericytes can also arise from the bone marrow-derived PDGFR- $\beta+$ PPCs $(33,35,56)$. Unlike ECs, pericyte markers including PDGFR- $\beta, \alpha$-SMA, desmin, and nerve/ glial antigen 2 proteoglycan (NG2) are not restricted to pericytes only $(37,56,58)$. In addition to PDGFR- $\beta$, NG2 has been shown to be important for pericyte recruitment to the blood vessels, as well as for their maturation and interaction with ECs (58). The studies of mouse GBM models revealed the presence of PPCs, but the 
level of their incorporation into the tumor vessels varies considerably, depending on the experimental model, the detection method and the markers used $(14,33,35,56)$. For example, Du et al. (33) found that approximately $2 \%$ of BMDCs infiltrating experimental GBM were PDGFR- $\beta+/$ Sca-1+ (stem cell antigen-1) PPCs.

\section{Contribution of myeloid cells to GBM neovascularization}

Myeloid cells $(\mathrm{CD} 45+)$ constitute different populations of BMDCs that contribute to tumor neovascularization, invasion, and progression. They, as pro-angiogenic support cells, have important roles in regulating the formation and maintenance of blood vessels in tumors $(14,31)$. These cell populations include tumor-associated macrophages (TAMs), TEMs, VEGFR-1+/CXCR4+ hemangiocytes, and myeloid-derived suppressor cells (MDSCs), among others $(31,33,39,64,65)$. The infiltration of tumors by CD45+ myeloid cells is regulated by hypoxia since the ablation of HIF- $1 \alpha$ in a GBM model substantially reduced the infiltration of these vascular modulatory cells, rendering tumors unable to induce neovascularization (33). SDF- $1 \alpha$ seems to be an important factor for the recruitment and retention of CD45+ myeloid cells $(14,33,35)$. These cells produce proangiogenic factors, cytokines, and proteases including MMPs (like MMP-9) $(31,33,39,64)$. BMDCs can make up over $20 \%$ of the cellular content of tumors such as GBMs (14).

\section{Tumor-associated microglia/macrophages}

The central nervous system contains different subsets of macrophages, most prominently including the parenchymal microglia and the perivascular macrophages (66). Thus, the brain tumor-associated microglia/macrophages (TAMs) appear to be mixed cell populations derived from the brain-resident microglia and the circulating monocytes. Activated /reactive microglia and macrophages (defined as F4/80+ in mice and CD68+ in humans) are frequently found to infiltrate gliomas, especially GBMs, and animal glioma models $(14,33,67$ - 70). In contrast to pro-inflammatory (classically activated) phenotype (M1) cells, tumor-infiltrating microglia/ macrophages become polarized (alternatively activated) to an M2 phenotype with anti-inflammatory properties and exhibiting the pro-angiogenic and pro-tumoral activity $(31,64,68,69,71)$. Glioma cells produce several factors that could recruit microglia/ macrophages, including macrophage chemoattractant protein- 1 and -3 (MCP-1, MCP-3), CSF-1 and HGF/SF (69, 71, 72). Microglia /macrophages represent the largest GBMinfiltrating population of cells (70). The number of microglia/macrophages is higher in GBM as compared to the grade II and III astrocytic gliomas and correlates with a higher vascular density (67). The proportion of M2 polarized (CD163+/CD204+) microglia/macrophages in human gliomas has also been shown to correlate with tumor grade, being the highest in GBM (68). These tumor-supportive cells in the GBM microenvironment can produce proangiogenic and other factors (such as VEGF, EGF, MMPs, TGF- $\beta$ ), contributing to angiogenesis, tumor growth, invasion, and immunosuppression (68 - 71).

\section{Tie-2-expressing monocytes}

TEMs are a subpopulation of circulating and tumor-infiltrating monocytes that express the receptor Tie-2 (39). TEMs express bFGF and MMP-9 and display a potent pro-angiogenic activity $(33,39)$. The Tie-2 ligand, Ang-2, is expressed by both hypoxic tumor cells and the ECs in tumor vessels $(18,26,31)$, and the upregulation of Ang-2 appears early in vascular remodeling in $\operatorname{GBM}(25,36)$, suggesting that tumor infiltration of TEMs could promote the angiogenic switch in GBM and tumor vascularization. TEMs in various tumors have been found to reside in both perivascular and hypoxic areas, and hypoxia upregulates Tie-2 expression on TEMs, increasing their responsiveness to Ang-2 (31).

\section{VEGFR-1+/CXCR4+ hemangiocytes}

Hemangiocytes have potent pro-angiogenic properties. These cells reside mainly in perivascular areas where they are thought to help stabilize blood vessels by releasing angiogenic factors (31). The observations that hypoxic tumor cells upregulate SDF- $1 \alpha$ and VEGF, and that HIF- $1 \alpha$-deficient GBM exhibit a reduced number of VEGFR-1+ hemangiocytes, indicate that these factors could recruit hemangiocytes into the hypoxic areas of tumors including GBM to promote tumor vascularization (14, 
33). These cells also express MMP-9 (33).

\section{Myeloid-derived suppressor cells}

MDSCs are a mixed population of myeloid cells with immunosuppressive activity, defined as CD11b+/Gr-1+ cells in mice and CD11b+/HLA-DR/CD33+ cells in humans $(31,65,73)$. In human GBMs, most of MDSCs (HLA-DR-/CD33+) were found to be lineage negative (CD14-/CD15-) (73). Under pathologic conditions, including tumors, this cell population drastically increases in the blood of patients and animal models and accumulates in tumors $(31,65,73)$. In a subcutaneous GL261 glioma model, MDSCs have been shown to be the main source of the immunosuppressive molecule TGF- $\beta$ in the tumor microenvironment (74). MDSCs upregulates the expression of arginase 1 and iNOS, among other factors, and suppress anti-tumor T-cell responses via several mechanisms $(64,65)$. However, MDSCs can also promote neovascularization in various tumors, including GBMs $(14,31,33)$. MDSCs express high levels of MMP-9, increasing the availability of VEGF in tumors (33). Moreover, some MDSCs have been shown to acquire an EC-like phenotype (express CD31 and VEGFR-2), suggesting that these MDSCs have the potential to differentiate and incorporate into the tumor endothelium (31). Recruitment of MDSCs into tumors is governed by chemotactic factors such as SDF-1 $\alpha$ (CXCL12), MCP-1 (CCL2), CXCL5 and Kit ligand $(\mathrm{SCF})$ that bind to and activate their respective receptors CXCR4, CCR2, CXCR2, and c-Kit (CD117) on MDSCs (31). In general, MDSCs and other proangiogenic myeloid cells contribute to tumor progression and neovascularization by both angiogenic and vasculogenic mechanisms. Moreover, blocking VEGF signaling may lead to the recruitment of these cells and vascular progenitors to restore tumor vascularization and growth $(53,75)$.

\section{Role of GBM stem cells in tumor neovascularization}

GSCs are a small population of cells within tumors that possess tumor-initiating capacity and properties such as self-renewal and multilineage differentiation, similar to neural stem cells (NSCs) (76, 77). These GSCs express NSC markers such as Nestin and CD133 (Prominin-1) (76 - 79), although CD133cells have been shown to be tumorigenic $(55,80)$. As GSCs are resistant to radiation and chemotherapy, their presence is thought to be responsible for tumor recurrence $(50,51,81)$. Similar to NSCs, GSCs reside around blood vessels, in vascular niches, that provide functional and structural support $(78,79)$. Notably, ECs interact closely with self-renewing GSCs and secrete factors that promote GSC proliferation and accelerate tumor initiation and progression (79). For example, nitric oxide (NO) secreted by ECs seems to support the stemness of GSCs via Notch activation (82). ECs express Notch ligands that may stimulate Notch receptors essential for GSC maintenance and self-renewal $(83,84)$. GSCs also regulated through expressing ECM receptors, such as integrin $\alpha 6$, that promote their maintenance (83). On the other hand, GSCs have been shown to promote tumor angiogenesis and vasculogenesis by secreting VEGF and SDF$1 \alpha(78,85)$. Since the Notch pathway plays a critical role in linking angiogenesis and GSC self-renewal, Notch is a potential therapeutic target in GBM (84). In addition, as vascular niches maintain GSCs, disruption of these niches with anti-angiogenic agents can ablate GSCs and arrest tumor growth, as seen in tumor-bearing mice (79).

Several studies have established the role of hypoxia in the maintenance of cancer stem cells, including GSCs in GBMs $(48,50,51,86,87)$. HIF- $1 \alpha$ has been shown to regulate GSCs $(86,87)$ and is preferentially expressed in the areas of necrosis (51, 87). HIF- $2 \alpha$ is preferentially expressed in GSCs and promotes survival and the stemness of GSCs, as well as their properties $(50,51)$. Further, it has been demonstrated that HIF- $2 \alpha$ was significantly present in GSCs, while HIF- $1 \alpha$ was present in both GSC and non-stem GBM cell populations, and was stabilized in more severe hypoxic conditions (50). Thus, within GBMs, depending on the tumor microenvironment, GSCs reside in vascular niches and also in hypoxic niches, contributing to angiogenesis and tumor growth $(50,51)$. The invasive edge of GBM is thought to contain GSCs, however, this invasive niche has not been well characterized (83).

Recent studies suggest that GSCs can directly participate in tumor vascularization by their ability to differentiate into vascular endothelium (vasculogenic mimicry) $(52,88,89)$. These studies identified that many of the ECs within GBMs contain the same genetic alterations as the tumor cells, indicating that these ECs are of neoplastic origin $(88,89)$. Furthermore, the implantation of GSCs in mice produced tumor xenografts with vessels composed of human ECs (88). It has been shown that blocking VEGF or 
silencing VEGFR-2 inhibits the maturation of tumor endothelial progenitors into endothelium, but does not prevent the differentiation of CD133+ GSCs into endothelial progenitors. However, blocking Notch1 does prevent the transition of GSCs into endothelial progenitors and vasculogenic mimicry (89). GBM stem cells express VEGFR-2 $(30,90)$, which is essential to sustain the stemness of GSCs and their capacity to initiate tumor vasculature and growth (90). In addition, GSCs have been shown to differentiate into pericytes to support vessel function and tumor growth (91). Since GSCs are resistant to chemoradiotherapy and contribute to tumor maintenance and recurrence, as well as to tumor vasculature, they represent an important target for novel and more effective therapeutic strategies $(81,83,92)$.

\section{ABNORMALITIES OF GBM NEOVASCULATURE}

Normal brain vasculature is highly specialized in terms of its structure and functions. ECs, pericytes, and astrocytes form and maintain the BBB. Prominent tight junctions between ECs are the principal anatomic component of the BBB (12). When gliomas attain a size beyond $1-2 \mathrm{~mm}$ in diameter, the BBB becomes compromised both structurally and functionally (13). The loss of BBB integrity and the morphological abnormalities of GBM vasculature, with elevated intratumoral levels of VEGF, results in increased tumor vessel permeability and interstitial edema $(13,15,22,25,27)$. The neovasculature in
GBMs is structurally and functionally abnormal. GBM vessels are tortuous and disorganized with abnormal ECs, decreased pericyte coverage, a larger vessel diameter, and thicker basement membranes than those of normal brain $(11-13,27,40)$. The endothelial tight junctions are opened and endothelium fenestratesin the tumor vasculature (12).

One of the histopathological hallmark features of GBM is MVP, a form of angiogenesis morphologically recognized as endothelial proliferation within newly sprouted vessels $(8,9)$. In its most florid form, MVP is characterized by the formation of glomeruloid vascular structures (Figure 1a). These tufted microaggregates (glomeruloid bodies) consist of multilayered, mitotically active ECs, accompanied by peri-ECs (pericytes) and basal lamina $(2,8,9,13$, 25). Astrocytic foot processes are typically absent (25). Vascular proliferation is seen throughout the tumor, often around necrotic foci and in the peripheral infiltrating zone (Figure 1b-d). Abnormal and highly permeable tumor vessels lead to non-uniform blood flow and heterogeneous delivery of oxygen and nutrients $(11,13)$. Consequently, tumors develop areas of hypoxia and eventually necrosis. Tumor microvessels are associated with an increased susceptibility to thrombosis and microhemorrhages (2, $8,15)$. The intravascular thrombosis in GBMs is present in over $90 \%$ of cases (6-8) and can accentuate and propagate tumor hypoxia and necrosis (7-9). These morphological abnormalities of tumor vasculature with functional consequences reflect the aggressive biology and clinical behavior of GBMs.

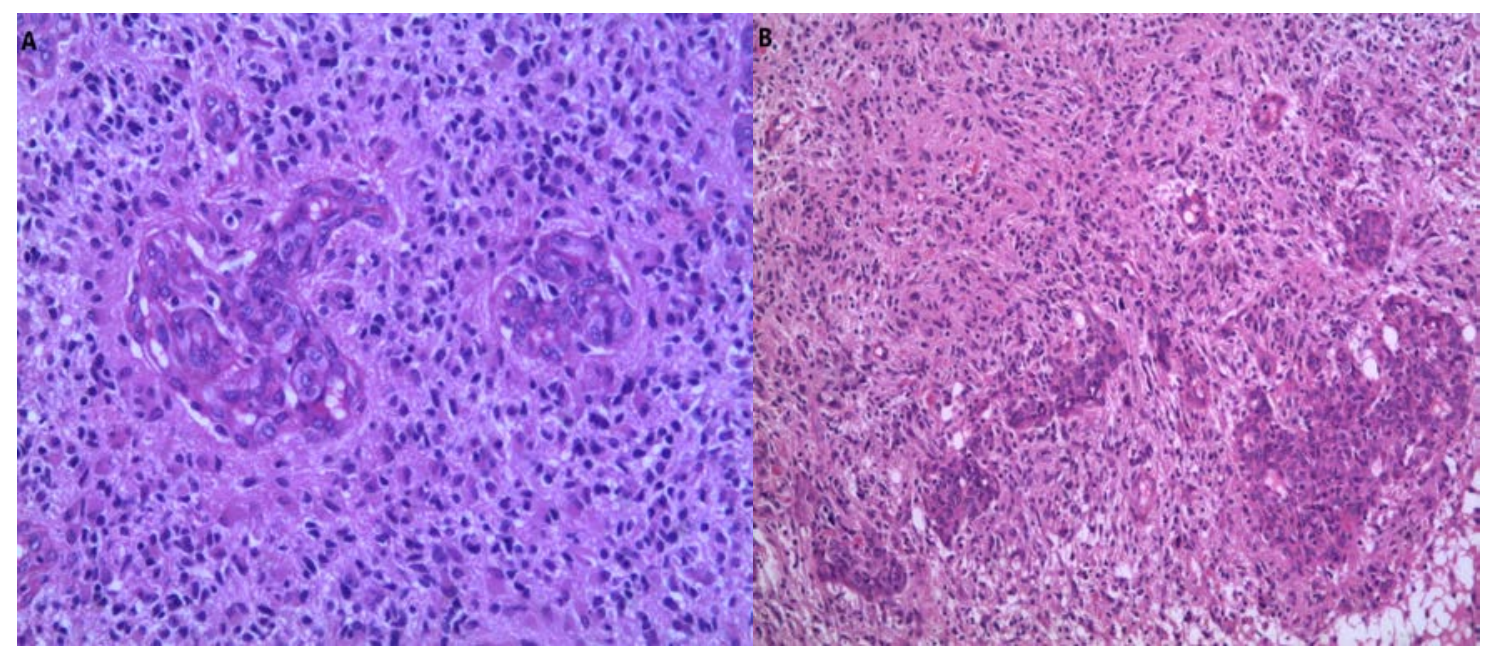

Figure 1. Microvascular proliferation (MVP) in glioblastoma (GBM): A) Glomeruloid multilayered Formation in GBM H\&Ex200 B) Marked MVP and large glomeruloid formation next to area of necrosis HEEx200 


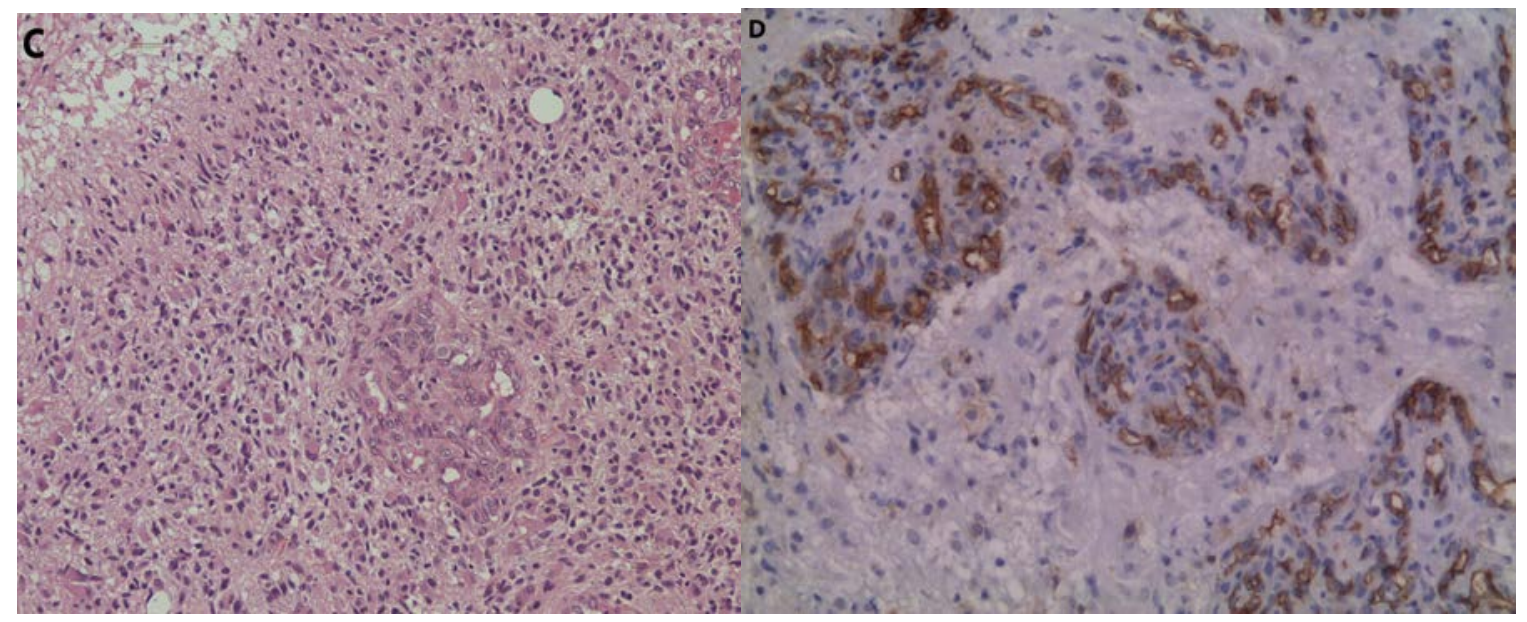

Figure 1. Microvascular proliferation (MVP) in glioblastoma (GBM): (C) MVP adjecent to the pseudo-palisading necrosis H\&Ex200 D) Large glomeruloid vascular structures in GBM, some of which with multi-canal formation (vascular endothelial cells are immuno-reactive for CD34x200

\section{ANTI-ANGIOGENIC THERAPY FOR GBM AND RESISTANCE TO THERAPY}

Anti-angiogenic (AA) therapy emerged as a promising option for treating highly vascularized GBMs. AA strategies tested in the clinic include targeting VEGF and/or VEGFR with antibodies or small-molecule tyrosine kinase inhibitors (TKIs) (17). Bevacizumab (BV), a recombinant humanized monoclonal antibody against VEGF (21) received approval by the FDA for use in recurrent GBM (rGBM). Phase II trials of $\mathrm{BV}$, demonstrating the radiographic response rates ranging from $28 \%$ to $57 \%$, also increased 6-month progression-free survival (PES) rates of 29 $46 \%$, and significant steroid-sparing effects (21, 93, 94). The initial phase II study noted that the addition of irinotecan to BV failed to produce an additive benefit (93). Several other studies reported that combining $\mathrm{BV}$ with various agents failed to improve outcomes beyond that of BV monotherapy, possibly due to a decrease in drug delivery in the tumor (23). However, a randomized phase II study of BV or lomustine as single agents or in combination in patients with rGBM (BELOB trial) reported promising results in the combination arm, with improved 6month PES and overall survival (OS) at 9 months (95). $\mathrm{BV}$ has also been evaluated in combination with radiation and temozolomide for newly diagnosed GBM (nGBM). Initial phase II studies noted a near doubling of median PES (13 - 14 months) compared with historical controls and a nominal median OS increment to 20 months $(23,96)$. Two randomized placebo-controlled phase III trials (RTOG 0825 and
AVAglio) demonstrated significant improvement in PES, but failed to demonstrate benefit on OS $(97,98)$.

Other VEGF-targeted inhibitors include aflibercept (VEGF-Trap), a chimeric soluble decoy receptor of VEGF (VEGF-A), VEGF-B, and PIGF. Aflibercept proved effective in preclinical models, but in a phase II study in patients with rGBM demonstrated minimal efficacy and poor tolerability (99). Cediranib (AZD2171), an oral pan-VEGFR TKI with additional activity against PDGFR- $\beta$ and c-Kit, was evaluated in a phase II study of patients with rGBM. Results were comparable to those reported for BV, with a radiographic response rate of over $50 \%$ and a 6-month PES of $26 \%$ (22). The cediranib therapy reduced blood vessel size and permeability, thus reducing vasogenic edema and corticosteroid requirements (22).

These clinical data support the hypothesis that AA therapy may transiently "normalize" the tumor vasculature (13). A phase Ib-II trial cediranib in combination with chemoradiotherapy in patients with nGBM showed favorable outcomes with a median OS of 20.2 months (24), which was comparable to the results of phase II studies with BV in combination with standard therapy in nGBM $(23,96)$. Numerous other VEGFR TKIs have been evaluated in clinical trials, including sorafenib, vatalanib, sunitinib, vandetanib, pazopanib and XL-184 (13, 15, 17, 24), however, these agents demonstrated limited efficacy in phase II studies in nGBM or $\operatorname{rGBM}(17,24)$. Randomized phase III trial with cediranib in rGBM failed to demonstrate OS benefit (23). Several other AA agents have been explored, such as the inhibitors 
of protein kinase $C-\beta$ (enzastaurin) and the integrins $\alpha v \beta 3$ and $\alpha v \beta 5$ (cilengitide), and angiopoietin inhibitors being tested, too (24). BV is the best-studied AA agent in GBM, and there are $>15$ active trials of BV for patients with nGBM and $>35$ active trials for patients with rGBM, some in combination with other agents in an attempt to avoid resistance to AA therapy (AAT) (17).

AA agents produce high radiographic response rates, reduce vasogenic brain edema, and prolong PES. However, the radiographic response might not correlate with a true clinical benefit (pseudoresponse) and tumor progression might occur as a nonenhancing progression (24). Although phase II studies demonstrated promising results and clinical improvement, randomized phase III trials failed to show an OS benefit for AA agents alone or in combination with chemoradiotherapy in $\operatorname{GBM}(17,23,97,98)$.

\section{Mechanisms of resistance to AA therapy}

Despite improvements in PES, patients with GBM treated with AAT eventually develop tumor progression (17). A fraction of patients are refractory to AAT (53). Resistance to such therapy may be adaptive (evasive) or inherent (intrinsic) (53). Several mechanisms have been proposed to explain these phenomena, which are related to changes in tumor cells, ECs, or other stromal cells $(13,38,53,75)$. For example, increased plasma levels of VEGF, SDF- $1 \alpha$, and PIGF after treatment with cediranib, vatalanib, and vandetanib were consistently observed in patients with either nGBM or rGBM $(17,22)$. Notably, plasma levels of bFGF and SDF- $1 \alpha$ were increased at the time of tumor progression in patients with rGBM treated with cediranib (22). These observations and preclinical data suggest that pro-angiogenic factors such as bFGF and PIGF can lead to the upregulation of alternative angiogenic pathways (22, 29, 53, 75). Hypoxia induced by vessel regression following AAT can also lead to the recruitment of BMDCs that have the capacity to fuel tumors by eliciting new blood vessels $(14,53,75)$. Recruitment of vascular progenitors (EPCs and PPCs) and CD45+ myeloid cells from the bone marrow through hypoxia-induced upregulation of SDF- $1 \alpha$ by HIF- $1 \alpha$ in preclinical GBM models $(33,35)$ suggest that the vasculogenic pathway may constitute a mechanism of adaptive (evasive) resistance to AAT. Accordingly, combinations of agents that target nonredundant vascular pathways may be necessary.
Other potential mechanisms of resistance to AAT include increased pericyte coverage to support tumor vessel stability and increased tumor cell invasiveness with vessel co-option $(38,53)$. Tumor vessels lacking adequate pericyte coverage are more susceptible to VEGF blockade (53) as pericytes provide pro-survival signals to ECs and suppress EC proliferation $(37,38,56)$. Improved protection of the tumor vessels by increasing pericyte coverage may render them more stable and less sensitive to AAT. Finally, preclinical $(12,33,53)$ and MRI data $(17,100)$ suggest that AAT may promote infiltrative tumor growth with co-option of the existing brain vessels. In mouse GBM models in which neovascularization was genetically or pharmacologically blocked, tumor cells were observed to co-opt normal blood vessels, achieving vascular sufficiency in a dispersed fashion, a phenotype known as a perivascular tumor invasion (53). In addition, an autopsy study in patients with rGBM treated with cediranib demonstrated a change in the growth pattern to a more infiltrative phenotype and increased expression of PDGF-C and c-Met (54), which may be implicated in GBM progression. Indeed, the overexpression of PDGF-C in tumor models (such as GBM) attenuates the response to antiVEGF therapy $(38,75)$. Preclinical evidence indicated that the c-Met signaling pathway promotes tumor growth and invasiveness as well as drug resistance (5). These adaptive mechanisms are not exclusive, and it is likely that several of them occur simultaneously in a single tumor $(17,38)$.

Intrinsic (inherent) resistance to AAT may be due to the pre-existing activation of multiple angiogenic pathways or a pre-existing inflammatory cell infiltrate (myeloid cells) that mediate vascular protection (53). Preclinical studies demonstrated that tumors showing no responsiveness to AAT were characterized by pre-existing infiltration of myeloid cells, principally CD11b+/Gr1+ cells $(53,75)$. Bv8 (also known as prokineticin-2) was upregulated in $\mathrm{CD} 11 \mathrm{~b}+/$ Gr1+ cells associated with anti-VEGF resistant tumors (75). Furthermore, GSCs reside in both vascular and hypoxic niches $(50,51)$, promoting tumor neovascularization, and even can differentiate into tumor ECs $(88,89)$ and target VEGF signaling can only partially inhibit this process (89). In addition, GSC-derived pericytes may render ECs less responsive to AAT in GBMs (91).

Since GBMs may be intrinsically resistant or evolve to become resistant to AAT, the identification of biomarkers or imaging parameters to predict 
response and to herald resistance is of high priority (23). Hypothesis-generating data from phase II trials in nGBM and rGBM revealed that there is an association between increased tumor perfusion and/or oxygenation (as a consequence of vascular normalization) and survival benefit $(17,23)$. This could indicate that tumor vascular normalization rather than vascular pruning may be an important therapeutic mechanism in GBM (17). Vascular normalization could increase tumor response to chemotherapeutics and radiotherapy $(13,23,38)$, whereas vascular pruning by AA agents can aggravate tumor hypoxia $(38,53)$. Therefore, the identification and validation of predictive biomarkers for selecting patients most likely to respond to AA agents are key steps to improving the therapeutic benefit from AA strategies $(5,17,23,24,38,75)$. In this regard, advanced imaging, circulating and tumor tissue biomarkers as candidates for predictive biomarkers require further validation $(5,17,23,24)$.

\section{CONCLUSION AND PERSPECTIVES}

AAT appears to be a promising option for the treatment of highly vascularized GBMs. However, resistance to AAT inevitably develops. Since tumors acquire vascular supply through several mechanisms (such as angiogenesis, vasculogenesis, vessel cooption, intussusceptions, and vasculogenic mimicry), a better understanding of the molecular and cellular basis of angiogenesis and other modes of GBM vascularization and the importance of tumor hypoxia and HIF-1 in promoting angiogenic and vasculogenic processes will allow the development of novel agents to target multiple vascular pathways. Resistance to AAT (both adaptive and intrinsic) remains a big challenge. Therefore, an improved understanding of the molecular mechanisms underlying GBM resistance to such therapy will be necessary to determine an appropriate combination of agents and patient selection, which may provide avenues for improving and sustaining the benefits from AA therapeutic strategies.

Further studies of GSCs and improved insights into their biology and microenvironmental interactions, and their contribution to tumor maintenance and recurrence, and tumor neovascularization through several mechanisms, including GSC-derived tumor endothelium and pericytes, will hopefully lead to target these cells effectively allowing a significant increase in the survival of patients with GBM.

\section{Acknowledgement}

This review paper is partially based on the doctoral thesis of dr. Irena Dimov which was not defended due to the author's premature death. 


\section{References}

1. Louis DN, Ohgaki H, Wiestler OD et al, eds. WHO Classification of Tumours of the Central Nervous System. Lyon: IARC, 2016.

2. Furnari FB, Fenton T, Bachoo RM et al. Malignant astrocytic glioma: genetics, biology, and paths to treatment. Genes Dev 2007; 21: 2683-710. https://doi.org/10.1101/gad.1596707

3. Zhang M, Ye G, Li J et al. Recent advance in molecular angiogenesis in glioblastoma: the challenge and hope for anti-angiogenic therapy. Brain Tumor Pathol 2015; 32: 229-36. https://doi.org/10.1007/s10014-015-0233-5

4. Stupp R, Mason WP, van den Bent MJ et al. Radiotherapy plus concomitant and adjuvant temozolomide for glioblastoma. N Engl J Med 2005; 352: 987-96.

https://doi.org/10.1056/NEJMoa043330

5. Touat M, Idbaih A, Sanson M et al. Glioblastoma targeted therapy: updated approaches from recent biological insights. Ann Oncol 2017; 28: 1457-72. https://doi.org/10.1093/annonc/mdx106

6. Tehrani M, Friedman TM, Olson JJ et al. Intravascular thrombosis in central nervous system malignancies: a potential role in astrocytoma progression to glioblastoma. Brain Pathol 2008; 18:164-71.

https://doi.org/10.1111/j.1750-3639.2007.00108.x

7. Brat DJ, Castellano-Sanchez AA, Hunter SB et al. Pseudopalisades in glioblastoma are hypoxic, express extracellular matrix proteases, and are formed by an actively migrating cell population. Cancer Res 2004; 64: 920-7.

https://doi.org/10.1158/0008-5472.CAN-03-2073

8. Brat DJ, Van Meir EG. Vaso-occlusive and prothrombotic mechanisms associated with tumor hypoxia, necrosis, and accelerated growth in glioblastoma. Lab Invest 2004; 84: 397-405.

https://doi.org/10.1038/labinvest.3700070

9. Rong $Y$, Durden DL, Van Meir EG et al."Pseudopalisading" necrosis in glioblastoma: a familiar morphologic feature that links vascular pathology, hypoxia, and angiogenesis. J Neuropathol Exp Neurol 2006; 65: 529-39. https://doi.org/10.1097/00005072-200606000-00001

10. Zagzag D, Lukyanov Y, Lan L et al. Hypoxiainducible factor 1 and VEGF upregulate CXCR4 in glioblastoma: implications for angiogenesis and glioma cell invasion. Lab Invest 2006; 86: 1221-32. https://doi.org/10.1038/labinvest.3700482

11. Acker T, Plate KH. Hypoxia and hypoxia inducible factors (HIF) as important regulators of tumor physiology. Cancer Treat Res 2004; 117: 219-48. https://doi.org/10.1007/978-1-4419-8871-3 14

12. Machein MR, Plate KH. Role of VEGF in developmental angiogenesis and in tumor angiogenesis in the brain. Cancer Treat Res 2004; 117: 191-218.

https://doi.org/10.1007/978-1-4419-8871-3 13

13. Jain RK, di Tomaso E, Duda DG et al. Angiogenesis in brain tumours. Nat Rev Neurosci 2007; 8: 610-22. https://doi.org/10.1038/nrn2175

14. Bergers G. Bone marrow-deived cells in GBM neovascularization. In: Van Meir EG (ed), CNS Cancer: Models, Markers, Prognostic Factors, Targets and Therapeutic Approaches. Humana Press (Springer), New York, 2009: 749-73. https://doi.org/10.1007/978-1-60327-553-8 31

15. Wong ML, Prawira A, Kaye AH et al. Tumour angiogenesis: Its mechanism and therapeutic implications in malignant gliomas. J Clin Neurosci 2009; 16: 1119-30.

https://doi.org/10.1016/j.jocn.2009.02.009 
16. Onishi $\mathrm{M}$, Ichikawa $\mathrm{T}$, Kurozumi $\mathrm{K}$ et al. Angiogenesis and invasion in glioma. Brain Tumor Pathol 2011; 28:13-24. https://doi.org/10.1007/s10014-010-0007-z

17. Lu-Emerson C, Duda DG, Emblem KE et al. Lessons from anti-vascular endothelial growth factor and anti-vascular endothelial growth factor receptor trials in patients with glioblastoma. J Clin Oncol 2015; 33:1197-213. https://doi.org/10.1200/JCO.2014.55.9575

18. Kaur B, Khwaja FW, Severson EA et al. Hypoxia and the hypoxia-inducible-factor pathway in glioma growth and angiogenesis. Neuro Oncol 2005; 7:134-53.

https://doi.org/10.1215/S1152851704001115

19. Dunn GP, Rinne ML, Wykosky J et al. Emerging insights into the molecular and cellular basis of glioblastoma. Genes Dev 2012; 26:756-84. https://doi.org/10.1101/gad.187922.112

20. Dimov I, Tasić D, Stefanović I et al. New insights into molecular basis of glioblastoma multiforme and associated immunosuppression. Acta Fac Med Naiss 2013; 30:165-84. (in Serbian). https://doi.org/10.2478/afmnai-2013-0009

21. Vredenburgh JJ, Desjardins A, Herndon JE II et al. Bevacizumab plus irinotecan in recurrent glioblastoma multiforme. J Clin Oncol 2007; 25: 4722- 9 .

https://doi.org/10.1200/JCO.2007.12.2440

22. Batchelor TT, Sorensen AG, di Tomaso E et al. AZD2171, a pan-VEGF receptor tyrosine kinase inhibitor, normalizes tumor vasculature and alleviates edema in glioblastoma patients. Cancer Cell 2007; 11: 83-95. https://doi.org/10.1016/j.ccr.2006.11.021

23. Batchelor TT, Reardon DA, de Groot JF et al. Antiangiogenic therapy for glioblastoma: current status and future prospects. Clin Cancer Res 2014; 20:5612-9.

https://doi.org/10.1158/1078-0432.CCR-14-0834

24. Tanaka S, Louis DN, Curry WT et al. Diagnostic and therapeutic avenues for glioblastoma: no longer a dead end? Nat Rev Clin Oncol 2013;
$10: 14-26$

https://doi.org/10.1038/nrclinonc.2012.204

25. Fischer I, Gagner JP, Law M et al. Angiogenesis in gliomas: biology and molecular pathophysiology. Brain Pathol 2005; 15: 297-310. https://doi.org/10.1111/j.1750-3639.2005.tb00115.x

26. Reiss $\mathrm{Y}$, Machein $\mathrm{MR}$, Plate $\mathrm{KH}$. The role of angiopoietins during angiogenesis in gliomas. Brain Pathol 2005: 15:311-7. https://doi.org/10.1111/j.1750-3639.2005.tb00116.x

27. $\mathrm{Hu} \mathrm{B}, \mathrm{Cheng}$ SY. Mechanisms of brain tumor angiogenesis. In: Van Meir EG (ed), CNS Cancer: Models, Markers, Prognostic Factors, Targets and Therapeutic Approaches. Humana Press (Springer), New York, 2009: 461-506.

28. Ferrara N, Gerber HP, LeCouter J. The biology of VEGF and its receptors. Nat Med 2003; 9: 669-76. https://doi.org/10.1038/nm0603-669

29. Kerbel RS. Tumor angiogenesis. N Engl J Med 2008; 358:2039-49. https://doi.org/10.1056/NEJMra0706596

30. D Alessio A, Proietti G, Lama G et al. Analysis of angiogenesis related factors in glioblastoma, peritumoral tissue and their derived cancer stem cells. Oncotarget 2016; 7: 78541-56. https://doi.org/10.18632/oncotarget.12398

31. Murdoch C, Muthana M, Coffelt SB et al. The role of myeloid cells in the promotion of tumour angiogenesis. Nat Rev Cancer 2008; 8:618-31. https://doi.org/10.1038/nrc2444

32. Lakka SS, Gondi CS, Rao JS. Proteases and glioma angiogenesis. Brain Pathol 2005; 15: 327-41. https://doi.org/10.1111/j.1750-3639.2005.tb00118.x

33. Du R, Lu KV, Petritsch C et al. HIF1 $\alpha$ induces the recruitment of bone marrow-derived vascular modulatory cells to regulate tumor angiogenesis and invasion. Cancer Cell 2008; 13: 206-20. https://doi.org/10.1016/j.ccr.2008.01.034

34. Lee S, Chen TT, Barber CL et al. Autocrine VEGF signaling is required for vascular homeostasis. Cell 2007; 130: 691-703. 
https://doi.org/10.1016/j.cell.2007.06.054

35. Aghi M, Cohen KS, Klein RJ et al. Tumor stromalderived factor-1 recruits vascular progenitors to mitotic neovasculature, where microenvironment influences their differentiated phenotypes. Cancer Res 2006; 66: 9054-64.

https://doi.org/10.1158/0008-5472.CAN-05-3759

36. Holash J, Maisonpierre PC, Compton D et al. Vessel cooption, regression, and growth in tumors mediated by angiopoietins and VEGF. Science 1999; 284: 1994-8.

https://doi.org/10.1126/science.284.5422.1994

37. Bergers G, Song S. The role of pericytes in bloodvessel formation and maintenance. Neuro Oncol 2005; 7: 452-64.

https://doi.org/10.1215/S1152851705000232

38. Carmeliet P, Jain RK. Molecular mechanisms and clinical applications of angiogenesis. Nature 2011; 473: 298-307.

https://doi.org/10.1038/nature10144

39. De Palma M, Venneri MA, Galli $R$ et al. Tie2 identifies a hematopoietic lineage of proangiogenic monocytes required for tumor vessel formation and a mesenchymal population of pericyte progenitors. Cancer Cell 2005; 8: 211-26.

https://doi.org/10.1016/j.ccr.2005.08.002

40. Guo P, Hu B, Gu W et al. Platelet-derived growth factor- $B$ enhances glioma angiogenesis by stimulating vascular endothelial growth factor expression in tumor endothelia and by promoting pericyte recruitment. Am J Pathol 2003; 162:108393.

https://doi.org/10.1016/S0002-9440(10)63905-3

41. Brat DJ, Bellail AC, Van Meir EG. The role of interleukin-8 and its receptors in gliomagenesis and tumoral angiogenesis. Neuro Oncol 2005; 7: 122-33.

https://doi.org/10.1215/S1152851704001061

42. Stevenson CB , Ehtesham M, McMillan KM et al. CXCR4 expression is elevated in glioblastoma multiforme and correlates with an increase in intensity and extent of peritumoral T2-weighted magnetic resonance imaging signal abnormalities. Neurosurgery 2008; 63:560-70. https://doi.org/10.1227/01.NEU.0000324896.26088.EF

43. Thurston G, Noguera-Troise I, Yancopoulos GD. The Delta-paradox: DLL4 blockade leads to more tumour vessels but less tumour growth. Nat Rev Cancer 2007; 7: 327-31.

https://doi.org/10.1038/nrc2130

44. Benedito R, Roca C, Sorensen I et al. The Notch ligands DLL4 and Jagged1 have opposing effects on angiogenesis. Cell 2009; 137: 1124-35. https://doi.org/10.1016/j.cell.2009.03.025

45. Zhang JF, Chen Y, Qiu XX et al. The vascular deltalike ligand-4 (DLL4)-Notch4 signaling correlates with angiogenesis in primary glioblastoma: an immunohistochemical study. Tumor Biol 2016; 37: 3797-805.

https://doi.org/10.1007/s13277-015-4202-8

46. Weis SM, Cheresh DA. Tumor angiogenesis: molecular pathways and therapeutic targets. Nat Med 2011; 17:1359-70.

https://doi.org/10.1038/nm.2537

47. Avraamides CJ, Garmy-Susini B, Varner JA. Integrins in angiogenesis and lymphangiogenesis. Nat Rev Cancer 2008; 8: 604-17. https://doi.org/10.1038/nrc2353

48. Keith B, Simon MC. Hypoxia-inducible factors, stem cells, and cancer. Cell 2007; 129: 465-72. https://doi.org/10.1016/j.cell.2007.04.019

49. Zagzag D, Zhong H, Scalzitti JM et al. Expression of hypoxia-inducible factor $1 \alpha$ in brain tumors: association with angiogenesis, invasion, and progression. Cancer 2000; 88: 2606-18.

https://doi.org/10.1002/10970142(20000601)88:11<2606::AIDCNCR25>3.0.CO;2-W

50. Li Z, Bao S, Wu Q et al. Hypoxia-inducible factors regulate tumorigenic capacity of glioma stem cells. Cancer Cell 2009; 15: 501-13. https://doi.org/10.1016/j.ccr.2009.03.018 
51. Seidel S, Garvalov BK, Wirta V et al. A hypoxic niche regulates glioblastoma stem cells through hypoxia inducible factor $2 \alpha$. Brain 2010; 133: 983-95. https://doi.org/10.1093/brain/awq042

52. El Hallani S, Boisselier B, Peglion F et al. A new alternative mechanism in glioblastoma vascularization: tubular vasculogenic mimicry. Brain 2010; 133: 973-82.

https://doi.org/10.1093/brain/awq044

53. Bergers G, Hanahan D. Modes of resistance to anti-angiogenic therapy. Nat Rev Cancer 2008; 8:592-603.

https://doi.org/10.1038/nrc2442

54. di Tomaso E, Snuderl M, Kamoun WS et al. Glioblastoma recurrence after cediranib therapy in patients: lack of "rebound" revascularization as mode of escape. Cancer Res 2011; 71: 19-28. https://doi.org/10.1158/0008-5472.CAN-10-2602

55. Sakariassen PO, Prestegarden L, Wang J et al. Angiogenesis-independent tumor growth mediated by stem-like cancer cells. Proc Natl Acad Sci USA 2006; 103: 16466-71. https://doi.org/10.1073/pnas.0607668103

56. Song S, Ewald AJ, Stallcup W et al. PDGFR- $\beta+$ perivascular progenitor cells in tumours regulate pericyte differentiation and vascular survival. Nat Cell Biol 2005; 7: 870-9.

https://doi.org/10.1038/ncb1288

57. Stratman AN, Malotte KM, Mahan RD et al. Pericyte recruitment during vasculogenic tube assembly stimulates endothelial basement membrane matrix formation. Blood 2009; 114: 5091101.

https://doi.org/10.1182/blood-2009-05-222364

58. Huang FJ, You WK, Bonaldo $\mathrm{P}$ et al. Pericyte deficiencies lead to aberrant tumor vascularization in the brain of the NG2 null mouse. Dev Biol 2010; 344: 1035-46.

https://doi.org/10.1016/j.ydbio.2010.06.023

59. Asahara T, Murohara T, Sullivan A et al. Isolation of putative progenitor endothelial cells for angiogenesis. Science 1997; 275:964-7. https://doi.org/10.1126/science.275.5302.964
60. Bertolini F, Shaked Y, Mancuso P et al. The multifaceted circulating endothelial cell in cancer: towards marker and target identification. Nat Rev Cancer 2006; 6: 835-45. https://doi.org/10.1038/nrc1971

61. Rafat N, Beck G, Schulte J et al. Circulating endothelial progenitor cells in malignant gliomas. J Neurosurg 2010; 112: 43-9. https://doi.org/10.3171/2009.5.JNS081074

62. Zheng PP, Hop WC, Luider TM et al. Increased levels of circulating endothelial progenitor cells and circulating endothelial nitric oxide synthase in patients with gliomas. Ann Neurol 2007; 62: 408.

https://doi.org/10.1002/ana.21151

63. Shaked Y, Ciarrocchi A, Franco M et al. Therapyinduced acute recruitment of circulating endothelial progenitor cells to tumors. Science 2006; 313:1785-7. https://doi.org/10.1126/science.1127592

64. Mantovani A, Sica A, Allavena P et al. Tumorassociated macrophages and the related myeloidderived suppressor cells as a paradigm of the diversity of macrophage activation. Hum Immunol 2009; 70: 325-30.

https://doi.org/10.1016/j.humimm.2009.02.008

65. Gabrilovich DI, Nagaraj S. Myeloid-derived suppressor cells as regulators of the immune system. Nat Rev Immunol 2009; 9: 162-74.

https://doi.org/10.1038/nri2506

66. Davoust N, Vuaillat C, Androdias G et al. From bone marrow to microglia: barriers and avenues. Trends Immunol 2008; 29:227-34. https://doi.org/10.1016/j.it.2008.01.010

67. Nishie A, Ono M, Shono $\mathrm{T}$ et al. Macrophage infiltration and heme oxygenase-1 expression correlate with angiogenesis in human gliomas. Clin Cancer Res 1999; 5: 1107-13.

68. Komohara Y, Ohnishi K, Kuratsu J et al. Possible involvement of the M2 anti-inflammatory macrophage phenotype in growth of human gliomas. J Pathol 2008; 216: 15-24. https://doi.org/10.1002/path.2370 
69. Yang I, Han SJ, Kaur G et al. The role of microglia in central nervous system immunity and glioma immunology. J Clin Neurosci 2010; 17: 6-10. https://doi.org/10.1016/j.jocn.2009.05.006

70. Hussain SF, Yang D, Suki D et al. The role of human glioma-infiltrating microglia/ macrophages in mediating antitumor immune responses. Neuro Oncol 2006; 8: 261-79.

https://doi.org/10.1215/15228517-2006-008

71. Wu A, Wei J, Kong LY et al. Glioma cancer stem cells induce immunosuppressive macrophages/ microglia. Neuro Oncol 2010; 12:1113-25. https://doi.org/10.1093/neuonc/noq082

72. Okada M, Saio M, Kito Y et al. Tumor-associated macrophage/microglia infiltration in human gliomas is correlated with MCP-3, but not MCP-1. Int J Oncol 2009; 34:1621-7.

https://doi.org/10.3892/ijo 00000292

73. Raychaudhuri B, Rayman P, Huang $\mathrm{P}$ et al. Myeloid derived suppressor cell infiltration of murine and human gliomas is associated with reduction of tumor infiltrating lymphocytes. J Neurooncol 2015; 122:293-301. https://doi.org/10.1007/s11060-015-1720-6

74. Umemura N, Saio $M$, Suwa $\mathrm{T}$ et al. Tumorinfiltrating myeloid-derived suppressor cells are pleiotropic-inflamed monocytes/macrophages that bear M1- and M2-type characteristics. J Leukoc Biol 2008; 83:1136-44.

https://doi.org/10.1189/jlb.0907611

75. Ferrara N. Pathways mediating VEGFindependent tumor angiogenesis. Cytokine Growth Factor Rev 2010; 21: 21-6. https://doi.org/10.1016/j.cytogfr.2009.11.003

76. Singh SK, Hawkins C, Clarke ID et al. Identification of human brain tumour initiating cells. Nature 2004; 432: 396-401. https://doi.org/10.1038/nature03128

77. Galli R, Binda E, Orfanelli U et al. Isolation and characterization of tumorigenic, stem-like neural precursors from human glioblastoma. Cancer Res 2004; 64: 7011-21. https://doi.org/10.1158/0008-5472.CAN-04-1364
78. Bao $\mathrm{S}, \mathrm{Wu} \mathrm{Q}$, Sathornsumetee $\mathrm{S}$ et al. Stem celllike glioma cells promote tumor angiogenesis through vascular endothelial growth factor. Cancer Res 2006; 66: 7843-8. https://doi.org/10.1158/0008-5472.CAN-06-1010

79. Calabrese C, Poppleton H, Kocak M et al. A perivascular niche for brain tumor stem cells. Cancer Cell 2007; 11: 69-82. https://doi.org/10.1016/j.ccr.2006.11.020

80. Beier D, Hau P, Proescholdt M et al. CD133(+) and CD133(-) glioblastoma-derived cancer stem cells show differential growth characteristics and molecular profiles. Cancer Res 2007; 67: 4010-15. https://doi.org/10.1158/0008-5472.CAN-06-4180

81. Nduom EK, Hadjipanayis CG, Van Meir EG. Glioblastoma cancer stem-like cells. Implications for pathogenesis and treatment. Cancer J 2012; 18:100-6. https://doi.org/10.1097/PPO.0b013e3182452e0d

82. Charles N, Ozawa T, Squatrito M et al. Perivascular nitric oxide activates Notch signaling and promotes stem-like character in PDGF-induced glioma cells. Cell Stem Cell 2010; 6:141-52.

https://doi.org/10.1016/j.stem.2010.01.001

83. Lathia JD, Heddleston JM, Venere M et al. Deadly teamwork: Neural cancer stem cells and the tumor microenvironment. Cell Stem Cell 2011; 8:482-5. https://doi.org/10.1016/j.stem.2011.04.013

84. Hovinga KE, Shimizu F, Wang R et al. Inhibition of Notch signaling in glioblastoma targets cancer stem cells via an endothelial cell intermediate. Stem Cells 2010; 28: 1019-29. https://doi.org/10.1002/stem.429

85. Folkins C, Shaked Y, Man S et al. Glioma tumor stem-like cells promote tumor angiogenesis and vasculogenesis via vascular endothelial growth factor and stromal-derived factor 1. Cancer Res 2009; 69: 7243-51.

https://doi.org/10.1158/0008-5472.CAN-09-0167

86. Soeda A, Park M, Lee D et al. Hypoxia promotes expansion of the CD133-positive glioma stem cells through activation of HIF-1 $\alpha$. Oncogene 2009; 28: 3949-59. 
https://doi.org/10.1038/onc.2009.252

87. Pistollato F, Abbadi S, Rampazzo E et al. Intratumoral hypoxic gradient drives stem cells distribution and MGMT expression in glioblastoma. Stem Cells 2010; 28: 851-62.

https://doi.org/10.1002/stem.415

88. Ricci-Vitiani L, Pallini R, Biffoni $\mathrm{M}$ et al. Tumor vascularization via endothelial differentiation of glioblastoma stem-like cells. Nature 2010; 468: 824-8.

https://doi.org/10.1038/nature09557

89. Wang $\mathrm{R}$, Chadalavada $\mathrm{K}$, Wilshire $\mathrm{J}$ et al. Glioblastoma stem-like cells give rise to tumour endothelium. Nature 2010; 468: 829-33. https://doi.org/10.1038/nature09624

90. Arbab AS, Jain M, Achyut BR. Vascular mimicry: the next big glioblastoma target. Biochem Physiol 2015; 4:e140.

91. Cheng L, Huang Z, Zhou W et al. Glioblastoma stem cells generate vascular pericytes to support vessel function and tumor growth. Cell 2013; 153: 139-52.

https://doi.org/10.1016/j.cell.2013.02.021

92. Dimov I, Tasić-Dimov D, Conić I et al.

Glioblastoma multiforme stem cells.

Sci World J 2011; 11:930-58.

https://doi.org/10.1100/tsw.2011.42

93. Friedman HS, Prados MD, Wen PY et al. Bevacizumab alone and in combination with irinotecan in recurrent glioblastoma. J Clin Oncol 2009; 27: 4733-40.

https://doi.org/10.1200//CO.2008.19.8721

94. Kreisl TN, Kim L, Moore K et al. Phase II trial of single-agent bevacizumab followed by bevacizumab plus irinotecan at tumor progression in recurrent glioblastoma.

J Clin Oncol 2009; 27: 740-5.

95. Taal W, Oosterkamp HM, Walenkamp AM et al. Single-agent bevacizumab or lomustine versus a combination of bevacizumab plus lomustine in patients with recurrent glioblastoma (BELOB trial): a randomised controlled phase 2 trial. Lancet Oncol 2014; 15: 943-53. https://doi.org/10.1016/S1470-2045(14)70314-6

96. Lai A, Tran A, Nghiemphu PL et al. Phase II study of bevacizumab plus temozolomide during and after radiation therapy for patients with newly diagnosed glioblastoma multiforme. J Clin Oncol 2011; 29: 142-8.

https://doi.org/10.1200/JCO.2010.30.2729

97. Gilbert MR, Dignam JJ, Armstrong TS et al. A randomized trial of bevacizumab for newly diagnosed glioblastoma. N Engl J Med 2014; 370: 699-708.

https://doi.org/10.1056/NEJMoa1308573

98. Chinot OL, Wick W, Mason W et al. Bevacizumab plus radiotherapy-temozolomide for newly diagnosed glioblastoma. N Engl J Med 2014; 370: 709-22

https://doi.org/10.1056/NEJMoa1308345

99. de Groot JF, Lamborn KR, Chang SM et al. Phase II study of aflibercept in recurrent malignant glioma: a North American Brain Tumor Consortium study. J Clin Oncol 2011; 29: 2689-95.

https://doi.org/10.1200/JCO.2010.34.1636

100. Narayana A, Kunnakkat SD, Medabalmi P et al. Change in pattern of relapse after antiangiogenic therapy in high-grade glioma. Int J Radiat Oncol Biol Phys 2012; 82: 77-82. https://doi.org/10.1016/j.ijrobp.2010.10.038 


\title{
Angiogeneza u glioblastomu: molekularni i ćelijski mehanizmi i klinička aplikacija
}

\author{
Desanka Tasić $^{2,4}$, Irena Dimov ${ }^{5}$, Miloš Kostov ${ }^{6}$, Nataša Vidović ${ }^{3}$, Dragan Dimov ${ }^{1,2}$ \\ ${ }^{1}$ Univerzitet u Nišu, Medicinski fakultet, Niš, Srbija \\ ¿Univerzitet u Nišu, Medicinski fakultet, profesor u penziji, Niš, Srbija \\ ${ }^{3}$ Centar za patologiju i patološku anatomiju, Klinički centar Niš, Niš, Srbija \\ ${ }^{4}$ Centar za patologiju i patološku anatomiju, Klinički centar Niš, patolog u penziji, Niš, Srbija \\ ${ }^{5}$ Univerzitet $u$ Nišu, Medicinski fakultet, Departman za imunologiju, Niš, Srbija \\ ${ }^{6}$ Institut za sudsku medicinu, Niš, Srbija
}

\section{SAŽETAK}

Glioblastom (GBM) je najčešći primarni maligni tumor mozga odraslih, sa lošom prognozom. Uprkos napretku u terapiji, nije postignut značajan porast preživljavanja bolesnika sa GBM. Ovi tumori recidiviraju kod većine bolesnika, a terapijske opcije za recidivantne tumore su ograničene. GBM su agresivni, brzorastući i izrazito infiltrišući tumori, sa obilnom angiogenezom (mikrovaskularnom proliferacijom) i nekrozom. Međutim, novoformirani tumorski sudovi strukturno i funkcionalno su abnormalni, sa stvaranjem polja hipoksije i nekroze, doprinoseći tumorskoj progresiji i agresivnosti. Pošto su GBM hipervaskularne prirode, ciljanje tumorske angiogeneze čini obećavajuću terapijsku strategiju.

U ovom revijalnom radu, autori sumiraju molekularne i ćelijske mehanizme angiogeneze GBM i druge načine vaskularizacije tumora, kao i ključne medijatore ovih procesa. Takođe, diskutuju o značaju tumorske hipoksije u promociji angiogenog i vaskulogenog procesa, doprinosu GBM matičnih ćelija u vaskularizaciji tumora i o antiangiogenoj terapiji za tretman GBM, kao i rezistenciji na ovu terapiju. Bolje razumevanje molekularne i ćelijske baze neovaskularizacije GBM, mehanizama rezistencije na terapiju i doprinosa GBM matičnih ćelija u formiranju vaskulature, vodiće razvoju efikasnijih terapijskih strategija.

Ključne reči: glioblastom, angiogeneza, vaskulogeneza, hipoksija, GBM matične ćelije, antiangiogena terapija, rezistencija 